DOI https://doi.org/10.18551/rjoas.2018-08.50

\title{
OPERATIONAL STRATEGIES FOR START-UP BUSINESS OF PEKING-DUCKS POULTRY INTEGRATED TO ECO-GREEN
}

\author{
Saefudin Asmudi*, Syah Tantri Yanuar Rahmat, Erni Nofi \\ Faculty of Economics and Business, Master's Degree of Management, \\ University of Esa Unggul, Jakarta, Indonesia \\ ${ }^{*}$ E-mail: asmudisaefudin@gmail.com \\ ORCID: 0000-0001-7050-4683
}

\begin{abstract}
The level of community's consumption in fowl meat especially duck is increasing as the trend of consuming varied duck meat in the restaurant is increasing as well. Duck husbandry business managed by PT Prima Duckindo with the concept of Eco-Green becomes a profitable business and becomes an example with the method of a dry, economical, and ecogreen housing. Peking duck husbandry with an integrated, economical, and eco-green intensive system uses Azolla microphyla plant and marsh fleabane leaf flour as the feed supplement and the use of other germ plasm. Peking duck husbandry with eco-green concept applies six husbandry managements which are: Eco-green Housing Farm Management; Breeding Management; Hatchery Management; Growing Management; Feeding Management; Azolla microphyla plant management and marsh fleabane plant management; Processing Management; Marketing Management.
\end{abstract}

\section{KEY WORDS}

Operational strategies, business, eco-green, poultry.

According to the data from Indonesian Central Bureau of Statistics (BPS), the province of Banten as the operational business region of peking ducks has 11,955,243 million residents or $4.66 \%$ of Indonesian citizens in 2015 (254.9 million citizens). The numbers of male citizens were 6,097,184 while female citizens were 5,858,059 (BPS of Banten Province). Based on the projection of BPS, the numbers of Banten citizens could reach 13.1 million people or $4.85 \%$ of the total 271.0 million people of Indonesian citizens in 2020 . Later in 2035, it is predicted that the numbers of Banten citizens would reach 16.0 million people or $5.24 \%$ of 305.6 million citizens of Indonesia. By the fact of the growth of the citizen population in Banten each year, it makes Banten a potential market which is big enough for the development of peking ducks business in the future.

Federation of Indonesian Poultry Society (FMPI) stated that the average consumption of meat among Indonesian citizens was $15 \mathrm{~kg} / \mathrm{capita} / \mathrm{year}$ from the total production or availability of 3.75 million tons. From that average consumption, broiler chickens fulfilled 9 $\mathrm{kg} /$ capita/year of the average meat consumption (2.25 million tons availability), cows and buffalos fulfilled $2.2 \mathrm{~kg} / \mathrm{capita} / \mathrm{year}$ (550 thousand tons availability), chicken stocks and laying chickens $1 \mathrm{~kg} / \mathrm{capita} / \mathrm{year}$ (250 thousand tons availability), local chickens $1 \mathrm{~kg} / \mathrm{capita} / \mathrm{year}$ (250 thousand tons availability), pigs $1 \mathrm{~kg} /$ capita/year, goats and sheep $0.5 \mathrm{~kg} / \mathrm{capita} /$ year (125 thousand tons availability), ducks $0.2 \mathrm{~kg} / \mathrm{capita} / \mathrm{year}$, and the other kind of meats 0.1 $\mathrm{kg} /$ capita/year (25 thousand tons availability). The level of animal protein consumption is still lower than the population of Indonesia with 254 million people. The needs of animal protein would significantly increase in the later time.

The contribution from the availability of duck meats is still low $0.2 \mathrm{~kg} / \mathrm{capita} / \mathrm{year}$ (50 thousand tons availability). This became an opportunity for business agents who intended to develop the potentiality of ducks to fulfill the needs of meats per $\mathrm{kg} / \mathrm{capita} / \mathrm{year}$ in the country. Nowadays, the reality among people appeared that duck meats were preferable than chicken meats since it is tastier and tender (Kompiang, 2009). In line with the improvement of society's prosperity and the variety of ducks cuisine, the shift of consumption pattern and 
trend among people has occurred (Ketaren, 2007). This phenomenon could be seen from the spreading of restaurants and food tents which offered duck meats as their main course.

The productivity of duck poultry could be improved by the implementation of government's policy to support the development of poultry production system or the establishment of technology innovation which was suitable for the poultrymen. The innovation of technology should reach not only poultry productivity, but also the treatment for poultry's health state and the poultry-products processing which is safe and halal. The implementation of government's policy to develop reliable poultrymen supported by universities was highly necessary to increase the contribution of duck meats in fulfilling the needs of foods from animals (Budiraharjo, 2009). Duck poultry was necessary to be innovated in terms of its management of traditional preservation which was supposed to be shifted, from the expensive and polluting modern-preservation into intensive, efficient, and eco-green preservation by implementing partnership system which was similar to its core. There were several factors affected ducks preservation such as the quality of the breeds, proper procedures of preservation, quality and the method of feeding, practical research and technology, good business system and financial analysis, adequate experience in preserving the ducks, strict biosecurity system, and marketing of the poultry products (Sukminiarti et al., 2007).

Peking Ducks Poultry with Eco-Green Integrated Concept. Intensive, integrated, economical, and eco-green peking ducks poultry utilized Azolla Microphylla and Plucheacea folium flour as the supplement of the food alongside the utilization of another germ plasm. Azolla Microphylla as the fito-remediation which recycled poultry waste water into clean water so that it reduced excessive water exploitation and smell pollution from the manure. The development of the poultry by strategic partnership was aimed to recruit traditional poultrymen to move into intensive poultry eco-green system and to become strategic partner for peking ducks poultry-company with mutually beneficial relationship in improving poultry productivity by a good management, assuring the availability of Day Old Duck (DOD) breed, food supplement Azolla Microphylla and Plucheacea folium flour to produce organicequivalent meats and marketing of poultry products which were competitive in price and beneficial. By this partnership pattern, a bigger network strength would be formed to protect poultry partners from cartel threats from bigger poultry association which often disadvantaged or even eliminated the business of smaller poultrymen. The threats were in the form of market price of poultry products which was too low, the scarcity of DOD, and the high price of poultry food. The partnership pattern could significantly improve the productivity of poultry products to fulfill the needs of duck meats in the province of Banten and its surrounding regions.

Peking ducks poultry with eco-green concept implemented six steps of poultry management: 1) Eco-Green Housing and Farm Management, 2) Breeding Management, 3) Hatchery Management, 4) Growing Management, 5) Feeding Management, 6) Azolla Microphylla and Plucheacea folium Management, 7) Processing Management, and 8) Marketing Management.

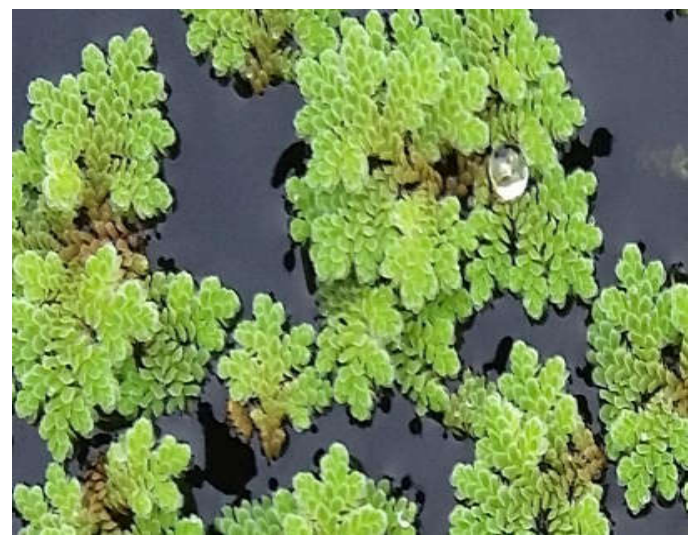

Figure 1 - Azolla Microphylla 

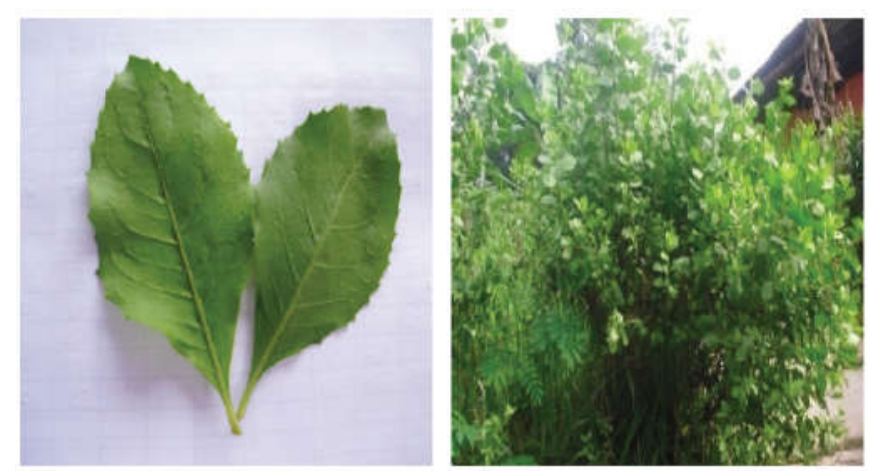

Figure 2 - Plucheacea folium

Business Market Opportunity of Peking Ducks. Consumption rate of the society towards poultry meats, especially ducks, was increasing alongside the trend of duck meats cuisine in many restaurants so that the needs of duck meats kept increasing. When the consumption of duck meats was increasing, ducks population in the province of Banten kept decreasing from year to year since there was no increase on ducks productivity by the poultry business agents. In 2012, ducks population in Banten consisted of 2,458,727 heads, it decreased by $16.78 \%$ in 2013 became $2,046,079$, in 2014 decreased by $0.14 \%$ became $2,043,189$ heads (BPS Banten). Referring to the data from BPS and Livestock Office of Banten, the needs of duck meats in Banten and its surrounding regions was predicted to experience deficiency for about 1,800 tons each year. It was concerned that in the future, Banten kept experiencing deficiency in availability and population which would cause fulfillment from other countries such as Thailand, Malaysia, and Vietnam, due to Asean Economic Community. As an example, frozen duck meats had entered Indonesia through Batam harbor in April to August 2015 to fulfill the deficiency of ducks needs in Indonesia. If this continued to happen, frozen duck meats would be easily entered Banten due to the urgent needs. Those conditions created an opportunity to peking ducks business to fulfill the needs of duck meats in Banten.

Operational Strategies:

Operational Framework. Prima Duckindo Inc. had a framework for the implementation of operational strategies which had to be accomplished to run duck poultry business. The operational framework was divided into two parts: pre-operation and during operation management. Pre-operation was the result of Quantitative Strategic Planning Matrix (QPSM) analysis as the tool which allowed the strategy maker to evaluate alternative strategy objectively and holistically, based on identified internal and external factors key of success (David et al., 2009). The legal permit and project management to establish the poultry was categorized into pre-operation activity.

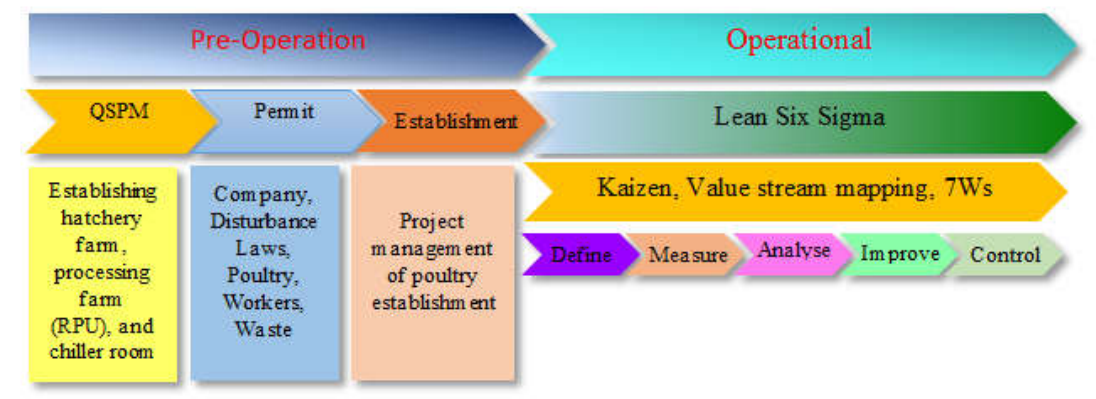

Figure 3 - Operational Framework of Prima Duckindo Inc.

In operational stage, Prima Duckindo Inc. selected Lean Six Sigma as industrial management for poultry. Ducks preservation by using intensive system in which the ducks were raised in a closed housing with ventilation adjusted to the climate and temperature of 
the room so that it comforted the ducks. Therefore, the production of commercial duck meats was a special business core which needed huge investment and precise time management.

Pre-operation. Management operational framework of Prima Duckindo Inc. which was carried out in pre-operation stage was QSPM. This analysis resulted an analysis to build integrated poultry starting from breeding, hatchery, growing, and processing farm as the operational objectives of the company. There were also several permits and rules that had to be implemented to ensure the sustainability of the company. Last but not least, there should be project management to organize integrated poultry.

Organizations made an effort to earn profit. Profit itself was not a single concept, however, it was originated from many implications such as: $P=$ Process excellence, $R=$ Resource management, $\mathrm{O}=$ Oriented to a goal, $\mathrm{F}=$ Financially strong, $\mathrm{I}=$ Innovative to stay ahead of competition, and $\mathrm{T}=$ Timely deployment of strategies. Most of traditional organizations defined profit as earning money without implementing appropriate operation. The effective method to this matter was Six Sigma and Lean Manufacturing originated from Toyota Production System (TPS), which were combined into Lean Six Sigma (LSS) (George and George, 2003).

In order to realize LSS management system, mapping for targets and operational objectives should be carried out comprehensively as a spirit of Kaizen (continuous improvement) (Chen and Shady, 2010). Industries and business environment reached competitive point to survive in market place. By following global economy, it demonstrated that just being good was not adequate, therefore, organizations were supposed to work hard to show their superiority to be able to survive in market place.

Table 1 - Operational objectives strategies of Prima Duckindo Inc.

\begin{tabular}{cll}
\hline $\mathrm{P}$ & $\begin{array}{l}\text { Process } \\
\text { excellence }\end{array}$ & $\begin{array}{l}\text { An effective and efficient process. This needed consistent and continuous improvement } \\
\text { with smaller variations. }\end{array}$ \\
\hline $\mathrm{R}$ & $\begin{array}{l}\text { Resources } \\
\text { management }\end{array}$ & $\begin{array}{l}\text { Systematic procedures to collect, keep, take, and validate required data for } \\
\text { organizations include human resources and its activities, and the characteristics of } \\
\text { organization units. }\end{array}$ \\
\hline $\mathrm{I}$ & $\begin{array}{l}\text { Innovative } \\
\mathrm{M}\end{array}$ & $\begin{array}{l}\text { Muscular of } \\
\text { financial }\end{array}$ \\
\hline $\mathrm{A}$ & $\begin{array}{l}\text { Associate to a } \\
\text { goal }\end{array}$ & Stable financial condition in its operation to be efficient in every division. \\
\hline $\mathrm{D}$ & $\begin{array}{l}\text { Deploy at right } \\
\text { time }\end{array}$ & Togetherness and awareness to achieve a goal as a team. \\
\hline
\end{tabular}

Source: Researcher's data.

Establishing a company in Indonesia was not too difficult since there has been rules to regulate it. Besides, coordination between departments of the government in reformation and digital era made the processes and procedures of permits easier and more transparent. The government continued to facilitate the procedures of starting a business. The numbers of enterprises in Indonesia was smaller than another neighboring country. Establishing a new company or enterprise would give plus point by creating more work opportunities and stirring local economy. One of the government initiatives was facilitating the establishment of Incorporated (Inc.). The steps of permits and regulations carried out by Prima Duckindo Inc. consisted of: Company Establishment Permit, Disturbance Laws Permit, Waste Permit, Poultry Enterprise Permit and Poultry Partnership Regulations.

Starting an enterprise activity required thorough planning so that the implementation would run well and precise in time. Prima Duckindo Inc. had a plan of running the enterprise which was named project management. Project management included establishing all building facilities, operational process, and selling. Prima Duckindo Inc. created a series of activities categorized as pre-operation activities. The implementation of the project was aimed to make the task scheduled and finished on time. Those activities were arranged in an activity program with detailed time in Gantt chart project management (Stevenson and Hojati, 2007). 
Operational. Table 2 was arranged to prepare operational strategies by examining product superiority of Prima Duckindo Inc.

Table 2 - The superiority of duck meats products from Prima Duckindo Inc.

\begin{tabular}{ll}
\hline No. & Detailed Information \\
\hline 1 & Lower price. \\
& $\begin{array}{l}\text { The market price was } 40,000 \text { Rupiahs } / \mathrm{kg} . \text { The price of Prima Duckindo Inc. was } 39,000 \text { Rupiahs } / \mathrm{kg} . \text { The } \\
\text { tolerance was minus } 2.5 \% .\end{array}$ \\
\hline 2 & $\begin{array}{l}\text { No fishy smell. } \\
\text { The duck meats of Prima Duckindo Inc. had no fishy smell since the fat layers between the skin and the } \\
\text { meat were eliminated by the feeding of } 1 \% \text { Plucheacea folium. }\end{array}$ \\
\hline 3 & $\begin{array}{l}\text { Low cholesterol. } \\
\text { The cholesterol was low according to the explanation above. }\end{array}$ \\
\hline 4 & $\begin{array}{l}\text { Tastier meat. } \\
\text { The food which contained plant protein was good for the ducks. }\end{array}$ \\
\hline 5 & $\begin{array}{l}\text { Eco-friendly. } \\
\text { Prima Duckindo Inc. put the priority on the responsibility to the environment, not only about money. }\end{array}$
\end{tabular}

The selection of Lean Six Sigma (LSS) management system became the superiority of the company compared to another poultry company (Snee, 2010). Achievement on the good quality of the product and industrial hygiene were essential to earn profit and achieve operational spirit by Process excellence which was combined with Eco-green model. In preparing the operation for integrated peking ducks poultry, Prima Duckindo Inc. planned and calculated the facility of the equipment, utility, production plan, capacity projection, and food availability.

Lean Six Sigma. Lean Six Sigma was a continuous improvement methodology which was combined with DMAIC (Define, Measure, Analyze, Improve, and Control) process and statistics analysis tool Six Sigma. It was then further combined to lean manufacture to significantly eliminate 8 waste as loses in value stream, tried to make the loses to zero. Lean Six Sigma was a process aimed to $6 \sigma$ (sigma) process (De Mast and Lokkerbol, 2012).

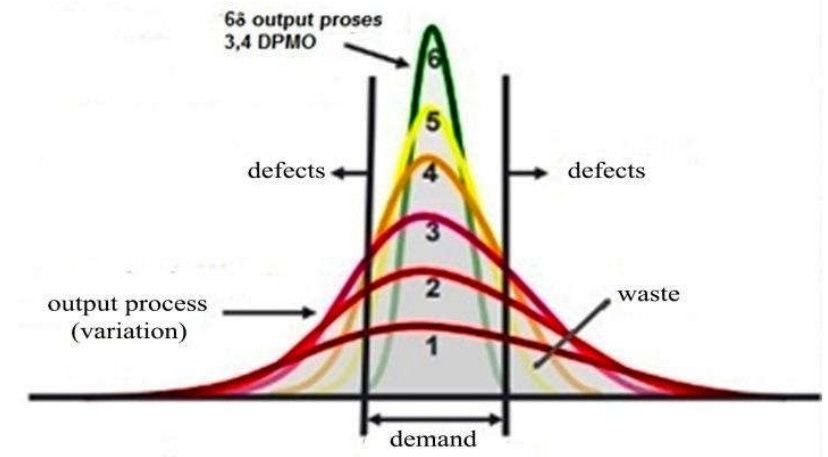

Figure 4 - Sigma and waste representation in normal distribution

Table 3 - Stages in six sigma

\begin{tabular}{llll}
\hline Sigma Stage & DPMO & Cpk & \% Yield \\
\hline $6 \sigma$ & 3,4 & 2,0 & 99,99966 \\
\hline $5 \sigma$ & 233 & 1,67 & 99,98 \\
\hline $4 \sigma$ & 6.210 & 1,33 & 99,38 \\
\hline $3 \sigma$ & 66.807 & 1,00 & 93,3 \\
\hline $2 \sigma$ & 308.537 & 0,67 & 69 \\
\hline $1 \sigma$ & 690.000 & 0,33 & 31 \\
\hline
\end{tabular}

Six sigma was a process in which 3, 4 defects occurred per one million opportunity/ Defects per Million Opportunities (DPMO). Two important steps in Lean Six Sigma to calculate variation were mean and standard deviation (Lucas, 2002). One of the important measurement in Lean Six Sigma was Sigma or standard deviation. Sigma was utilized as 
metric to calculate variation in the process. The tighter the variation, the better the quality of the process. A process was considered as six sigma if six standard deviations were appropriate to each mean process and customer specification. This was equivalent to $\mathrm{Cpk}=$ 2.0 .

The main principal of lean was improvement in the below-line through waste elimination in value stream and as identified by the customers. Value-added activities included the activities which the customer agreed to pay. Activities without added value were considered as a waste. The things which the customer agreed to pay were considered as added value to the products, services, or units. The activities included the process of creating finished products from raw materials. Non value-added activities consisted of 8 type of waste, which was called DOWNTIME: Defects, Over-production, Waiting, Non-utilized Resources/Talent, Transportation, Inventory, Motion, and Excess Processing (Sim-Tang, 2006).

Define. Define was the step to determine the problem and give limitation to the improvement activities. In this step, production process and value chain identification to customer value were carried out by using SIPOC (Supplier-Input-Process-Output-Customer). In the poultry of Prima Duckindo Inc., there were a throughput and improvement to be understood since those were very important to understand the process of ducks poultry. SIPOC would help the owners or investors and stakeholders or the owner of Prima Duckindo Inc. to determine the limitations to make. Supply chain was a global network utilized to deliver products (goods and/or services) from raw materials to the customer through an information stream, physical distribution, and cash flow (Parkash and Kaushik, 2011).

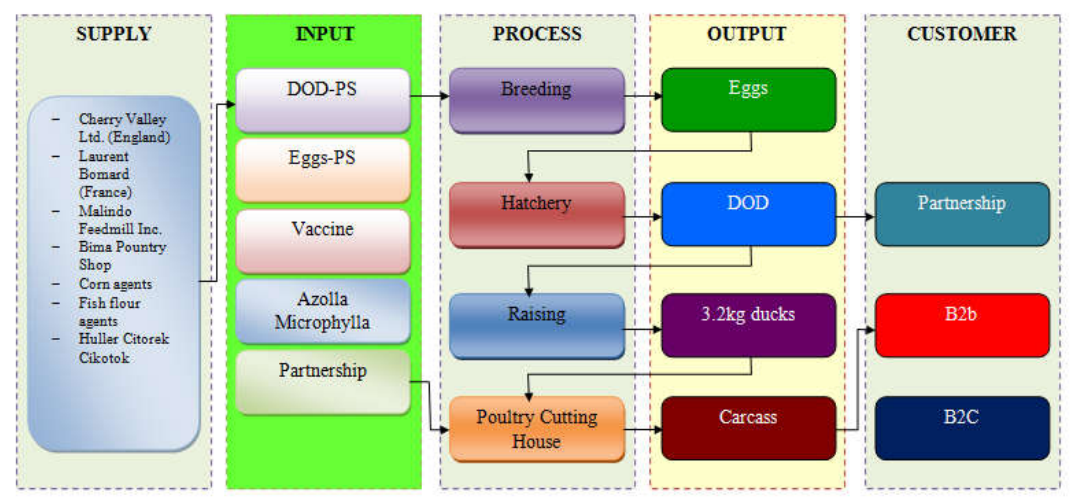

Figure 5 - SIPOC Diagram of Prima Duckindo Inc.

Supply Chain Management in Prima Duckindo Inc. designed the poultry with thorough planning by using biosecurity control system, good AMDAL, and monitoring of the supply chain activities to produce net value, establishing competitive infrastructure, making the most use of logistics, synchronizing the supply and demand, and measuring performance globally.

Measure. This step was aimed to measure the whole production process by measuring standard time of each activity process. This was done by making value stream mapping, presenting seven waste along value stream, determining critical of waste towards the most influencing waste using Diagram Pareto and determining DPMO and sigma level on waste defect (Ravichandran, 2007).

VSM was one of the effective lean tools to eliminate waste, mapping the flow of the materials, providing information in production system, identifying long-term vision and developing plans to achieve targets (Martin and Osterling, 2014). VSM was defined as the mapping of both value-added and non-value-added activities which were needed for production process from raw materials into final products. In utilizing VSM, a production system was not seen from a single side, however, it was seen as a whole production system. VSM was useful to execute on-going improvement system. In short, main objective of VSM was to identify all waste in production stream and eliminate them. 


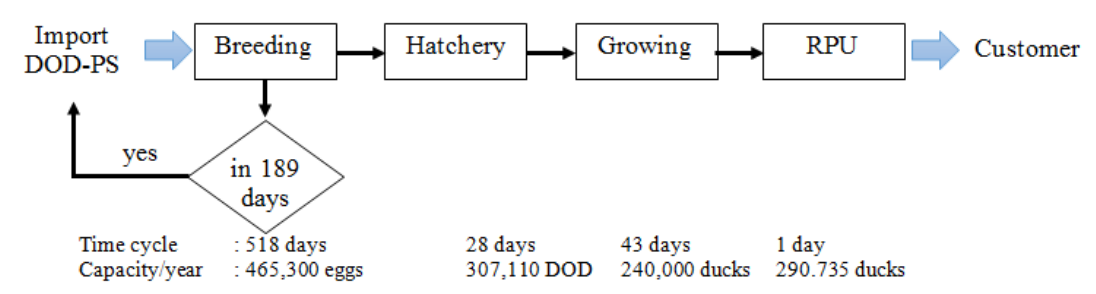

Figure 6 - Value stream mapping

The planning of production process stream for integrated peking ducks poultry in Prima Duckindo Inc. was arranged as on Figure 7.

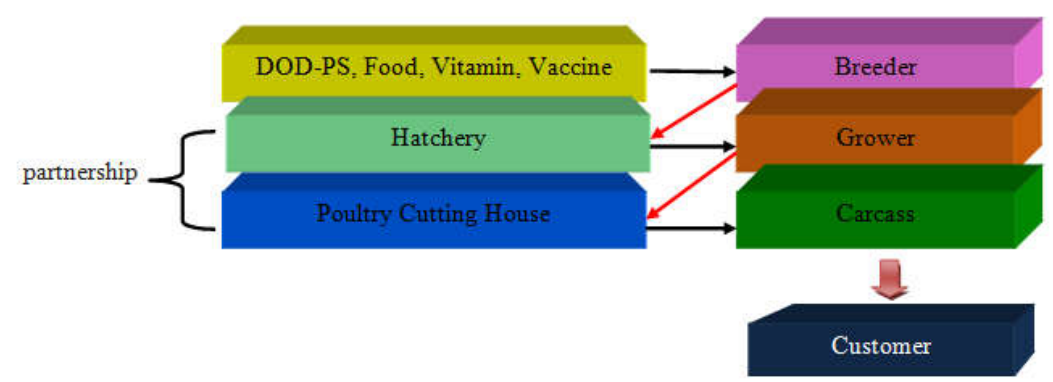

Figure 7 - Diagram of production process stream poultry in Prima Duckindo Inc.

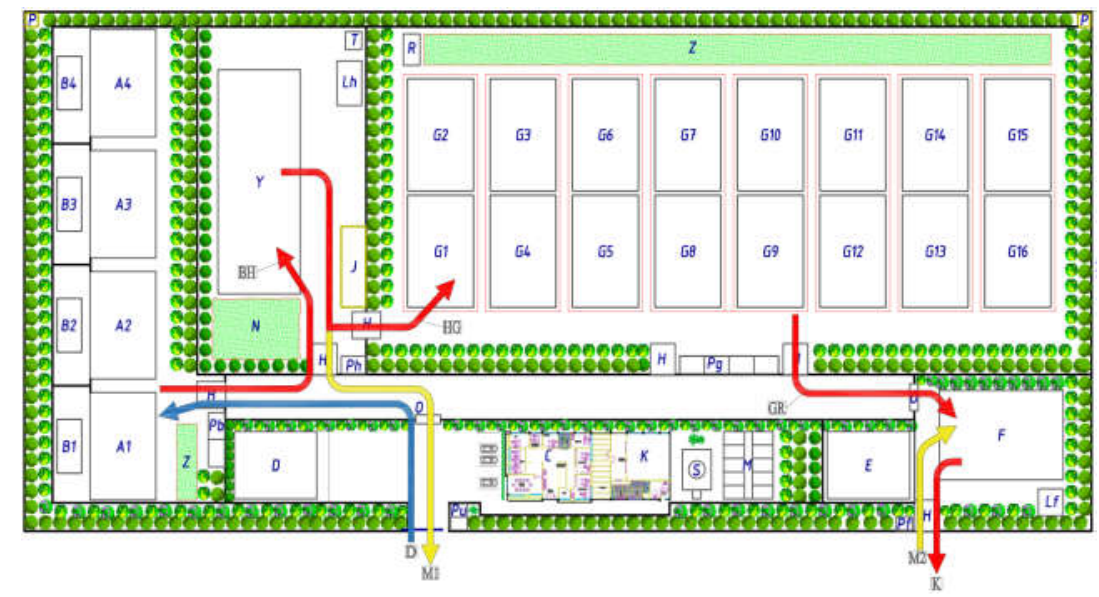

Figure 8 - Visual process stream in the poultry (Source: Researcher's data)

Table 4 - Explanation of process stream

\begin{tabular}{ll}
\hline Symbol & Explanation \\
\hline D & The process of DOD-Parent stock entering to Breeding house after it was ordered from the suppliers. \\
\hline BH & $\begin{array}{l}\text { The process of egg collecting from the breeder which would be stored in Hatchery. Those eggs were } \\
\text { hatched and would become DOD-Final Stock }\end{array}$ \\
\hline HG & The process of preservation from DOD-Final stock in Hatchery to Grower house to be raised into ducks. \\
\hline M1 & Delivery of DOD-Final stock to the partners of Prima Duckindo Inc. to be raised into ducks. \\
\hline GR & Harvesting of ducks from Grower to Processing Farm to be made into fresh carcass. \\
\hline M2 & Delivering harvested ducks from partners to Processing Farm of Prima Duckindo Inc. \\
\hline K & Distribution process of fresh carcass from Processing farm to the consumers. \\
\hline
\end{tabular}

Process capability was utilized to evaluate the capability of performance in a company or organization to produce goods or service based on the calculation from control chart. The following presented an example to calculate process capability from the weight of the egg in Hatchery $60-70$ gram as the standard to produce DOD weight 55 gram.

A process was defined as a series of activities which turned input into output. The process changed from time to time. Determining whether a change occurred was an 
important point for improvement (Kane, 1986). Run chart was utilized to determine whether central tendency from a process experienced a change. There was no need to use complex calculation or particular software, we could analyzed the value on axis $Y$ and time on axis $X$. Run chart was utilized alternately with term-series graphics. In some cases, run chart was similar to control diagram which was utilized in process control statistics, but it did not present the limit of process control.

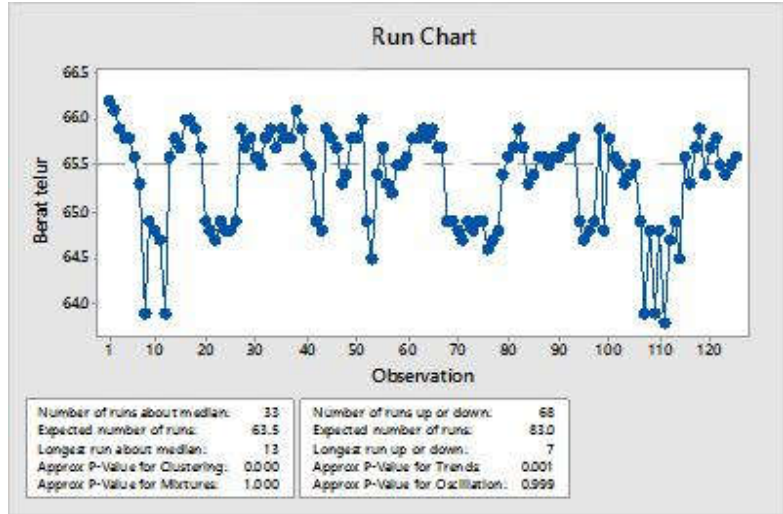

Figure 9 - Run chart for the weight of eggs (Source: Researcher's data)

Run chart could be utilized to study the observation of trend or pattern during certain period of time and focused on important changes in the process. Run chart could determine whether a process had general causes or variation of specific causes. This was essential since a process always existed in one of these 4 phases: ideal, limit threshold, chaos threshold. and chaos. If a process stood in ideal phase, it showed stability and target of performance from time to time. This process could be predicted and the result would fulfill customers' expectation. In chaos threshold, the process could not be predicted, but the final result was still able to fulfill customers' expectation. However, in chaos phase, the process would not be able to be predicted and the final result would not fulfill customers' expectation.

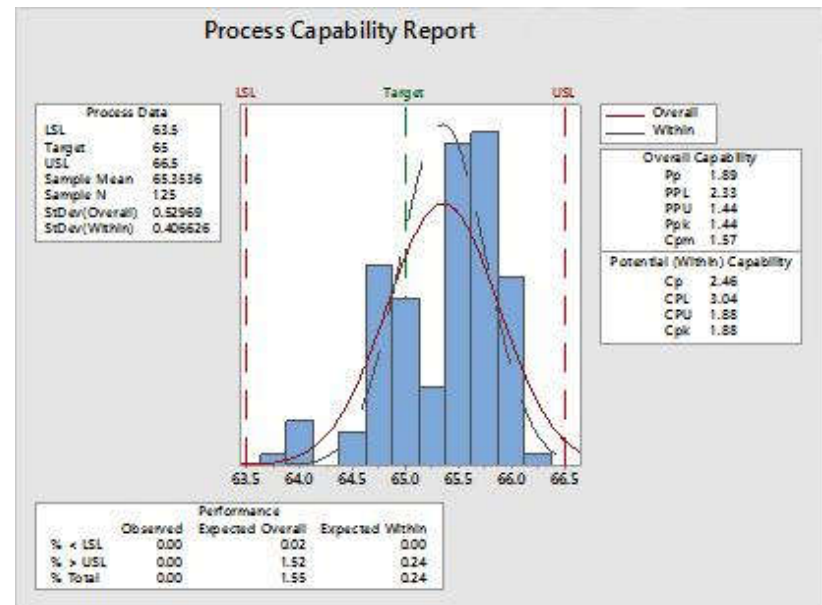

Figure 10 - Process Capability for the weight of eggs (Source: Researcher's data)

Process capability $(\mathrm{Cp})$ could be categorized as:

- if $\mathrm{Cp}>1.33$ : the process was satisfying;

- if $\mathrm{Cp}>1.80$ : very good process control;

- if $1<\mathrm{Cp}<1.30$ : process should be monitored \& variation should be reduced;

- if $\mathrm{Cp}<1$ : improvement process was crucial and must be done soon.

Analyze. In this step, several analyses were carried out to look for the causes of the problems, one of which was by using Pareto Diagram. In its implication, Pareto Diagram was 
highly useful in determining and identifying the priority of the problems to be solved. The problem which often occurred was our main priority to do something.

Pareto Diagram was one of six sigma tools which was frequently utilized in quality control. Basically, Pareto Diagram was bar graphics which presented the problems based on the total numbers of the occurrence (Tague, 2005). The order started from the most frequent problem to the least frequent one. In the graphics, it was showed by the highest bar (left) and lowest bar (right).

One of the analyses carried out in this step was finding the highest production cost in Breeder division.

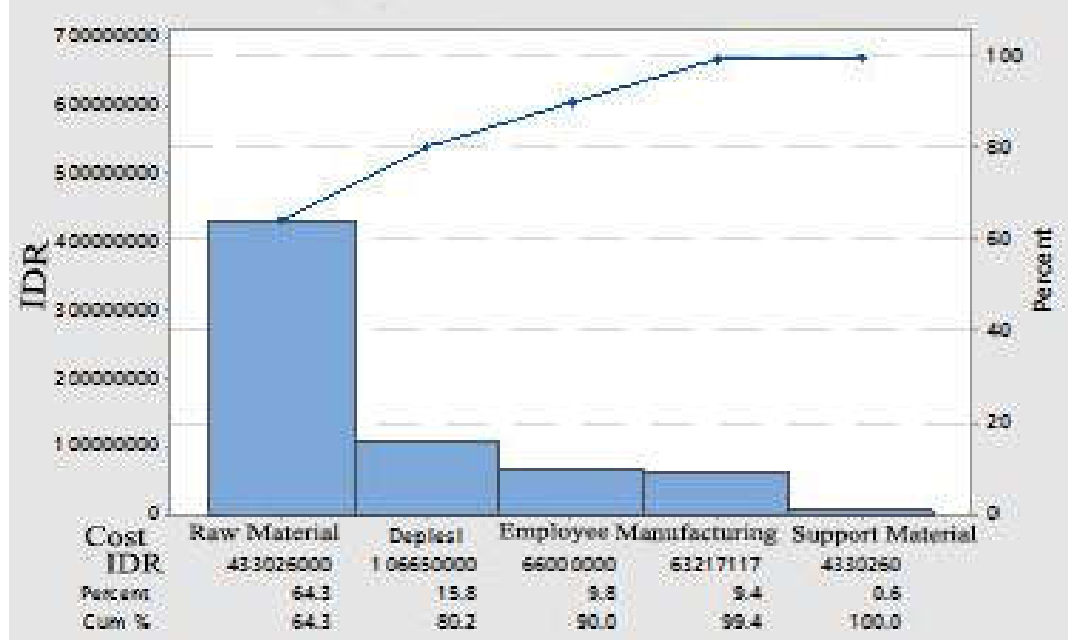

Figure 11 - Pareto Diagram of Breeder's production cost in 2018

In the food storage inside raw materials warehouse, Prima Duckindo Inc. always implemented a system called first in first out (FIFO). This system resulted with no decreasing quality of the food, therefore, the health of the ducks was guaranteed and the weight was appropriate with the standard. To minimize storage and food supply cost, Prima Duckindo Inc. implemented Economic Order Quantity (EOQ) system to spend the cost in the form of food or food storage so that the cost for another facility could be minimized and the cost could be used for another aspect.

The need of raw materials in 2018 was presented in the following graphics:

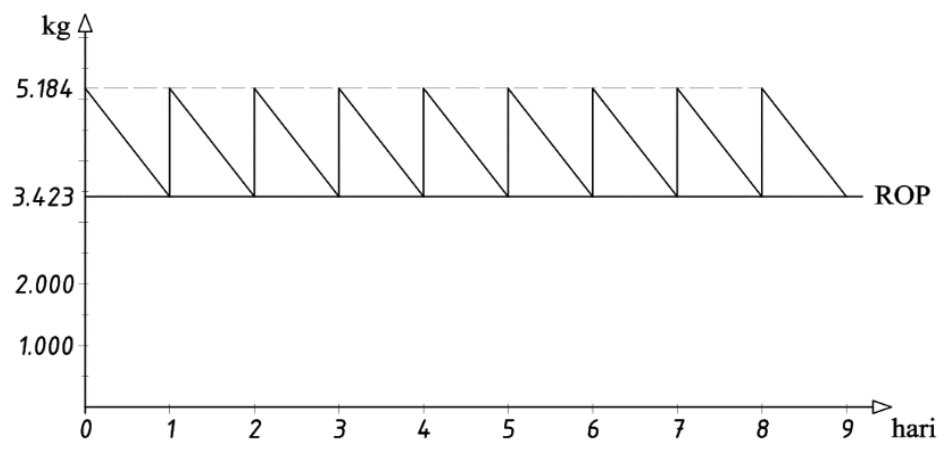

Figure 12 - Graphics of the needs of the food in 2018 (Source: Researcher's data)

Based on the analysis on this step, the highest production cost in Breeder division was raw materials. Almost $64.3 \%$ of total production cost was spent to fulfill the needs of raw materials.

Generally, production plan is a plan in which a series of production activities would occur from input, processing, and output. Production plan to be implemented by Prima Duckindo is the production of peking ducks would be adjusted to the condition of integrated housing system, starting from providing breeder. Preservation of breeder in breeder house 
would require 72 weeks (approximately 1.5 years). When it comes time for laying, the breeder's eggs would be collected every 3 days. Those eggs then would be hatched in hatchery division for 30 days. DOD ducks would be produced from hatchery division to be raised in both internal or partnership grower division for maximum 45 days to reach $3.2 \mathrm{~kg}$ of weight. Once in 3 days, would be produced ducks with standard weight from one of grower houses. Those ducks would be processed in processing farm (RPU) into carcass to be stored in cooling area so that it keeps fresh. Production capacity to be implemented by Prima Duckindo for 5 years would be carried out by increasing 30\% capacity per year starting from the second year to fulfill market demands.

Table 5 - Plan of food supply for 5 years ahead

\begin{tabular}{lllllll}
\hline \multirow{2}{*}{ No } & \multirow{2}{*}{ Description } & \multicolumn{5}{c}{ Year } \\
\cline { 3 - 6 } & & 2018 & 2019 & 2020 & 2021 & 2022 \\
\hline 1 & Breeder & 72.171 & 126.846 & 161.109 & 207.401 & 270.824 \\
\hline 2 & Grower & 338.39 & 924.611 & 1.195 .517 & 1.449 .358 & 1.582 .387 \\
\hline 3 & Total needs of food & 410.561 & 1.051 .457 & 1.356 .626 & 1.656 .759 & 1.853 .211 \\
\hline 4 & Food warehouse cost & 2.160 .000 & 2.160 .000 & 2.160 .000 & 2.160 .000 & 2.160 .000 \\
\hline 5 & Storage cost & 5,30 & 2,10 & 1,60 & 1,40 & 1,20 \\
\hline 6 & Order cost & 20 & 20 & 20 & 20 & 20 \\
\hline 7 & Needs/day & 1.141 & 2.921 & 3769 & 4603 & 5148 \\
\hline 8 & Reorder Point & 3.423 & 8763 & 11307 & 13809 & 15444 \\
\hline 9 & $\mathrm{Q}^{*}(\mathrm{~kg})$ & 1.761 & 4476 & 5824 & 6881 & 7860 \\
\hline 10 & $\mathrm{~N}$ & 234 & 235 & 233 & 241 & 236 \\
\hline
\end{tabular}

Table 6 - 7W's Approach and Technique

\begin{tabular}{|c|c|c|c|c|c|c|}
\hline $\begin{array}{l}\text { Category } \\
\text { Of Waste }\end{array}$ & $\begin{array}{l}\text { Type Of } \\
\text { Waste }\end{array}$ & $\begin{array}{l}\text { Waste } \\
\text { Reduction } \\
\text { Approach }\end{array}$ & Method & $\begin{array}{l}\text { Focus } \\
\text { Points }\end{array}$ & $\begin{array}{l}\text { Principal } \\
\text { Worksheets }\end{array}$ & $\begin{array}{l}\text { Desired } \\
\text { Result }\end{array}$ \\
\hline People & $\begin{array}{l}\text { Processing } \\
\text { Motion } \\
\text { Waiting }\end{array}$ & $\begin{array}{l}\text { Workplace } \\
\text { Management }\end{array}$ & $\begin{array}{l}\text { Standard Work } \\
\text { Workplace } \\
\text { Organization } \\
\text { Kaizen } \\
20 \text { Keys }\end{array}$ & $\begin{array}{l}\text { Layout } \\
\text { Labeling } \\
\text { Tools/Parts } \\
\text { Arrangement } \\
\text { Work Instructions } \\
\text { Efficiency } \\
\text { Takt Time } \\
\text { Skills Training } \\
\text { Shift Meetings } \\
\text { Cell/Area Teams } \\
\text { Visual Displays }\end{array}$ & $\begin{array}{l}\text { Standard Work } \\
\text { Sheet (SWS) } \\
\text { Time Observation } \\
\text { Form (TOF) } \\
\text { Standard Work } \\
\text { Combination } \\
\text { Sheet (SWCS) } \\
\text { Work Load } \\
\text { Balancing Sheet } \\
\text { (WLBS) } \\
\text { Kaizen Target } \\
\text { Sheet (KTS) } \\
\text { Kaizen Action } \\
\text { Sheet (KAS) } \\
\end{array}$ & $\begin{array}{l}\text { Highly } \\
\text { Efficient, } \\
\text { Safe } \\
\text { Work } \\
\text { Areas } \\
\text { With } \\
\text { High } \\
\text { Output }\end{array}$ \\
\hline Quantity & $\begin{array}{l}\text { Inventory } \\
\text { Moving } \\
\text { Things } \\
\text { Making Too } \\
\text { Much }\end{array}$ & Just-in-time & $\begin{array}{l}\text { Leveling } \\
\text { Kanban } \\
\text { Quick Setup } \\
\text { Preventive } \\
\text { Maintenance }\end{array}$ & $\begin{array}{l}\text { Work Balance } \\
\text { WIP } \\
\text { Location/Amount } \\
\text { Kanban Location } \\
\text { Kanban Types } \\
\text { Lot Sizes } \\
\text { Changeover Analysis } \\
\text { PM Analysis }\end{array}$ & $\begin{array}{l}\text { SWS } \\
\text { SWCS } \\
\text { WLBS } \\
\text { Kanbans } \\
\text { Table of } \\
\text { Production } \\
\text { Capacity By } \\
\text { Process (TPCP) } \\
\text { PM Scheduling } \\
\text { Sheet (PMSS) }\end{array}$ & $\begin{array}{l}\text { What } \\
\text { You } \\
\text { Need, } \\
\text { When } \\
\text { You } \\
\text { Need } \\
\text { It }\end{array}$ \\
\hline Quality & $\begin{array}{l}\text { Fixing } \\
\text { Defects }\end{array}$ & $\begin{array}{l}\text { Error } \\
\text { Proofing } \\
\text { Autonomation }\end{array}$ & $\begin{array}{l}\text { Detection } \\
\text { Warning } \\
\text { Prediction } \\
\text { Prevention } \\
\text { Jidoka }\end{array}$ & $\begin{array}{l}\text { Appropriate Automated } \\
\text { Assistance } \\
\text { Modifications } \\
\text { Successive Checks } \\
\text { Check Sheets } \\
\text { Templates, } \\
\text { Etc. } \\
\text { Cross Training }\end{array}$ & $\begin{array}{l}\text { SWCS } \\
\text { Error Proofing } \\
\text { Action Sheet } \\
\text { (EPAS) } \\
\text { Error Proofing "To } \\
\text { Do" List (EPL) } \\
\text { Skill Versatility } \\
\text { Visual Display }\end{array}$ & $\begin{array}{l}\text { Good } \\
\text { Quality }\end{array}$ \\
\hline
\end{tabular}

Improve. Improve was a phase in DMAIC cycle to fix the problems occurred in define, measure, and analyze phase according to the data. The next step was giving recommendation of improvement then followed by selecting priority of improvement recommendation by using failure mode and effect analysis (FMEA). Improvement 
recommendations included alternative feeding to reduce the cost for food. The answer of this problem was by giving Azolla Microphylla as feeding alternative. Improvement in the field was carried out to determine which waste would be the priority to be fixed. Improvement suggestion to minimize waste from production process was carried out by using seven kinds of wasting as in Table 6.

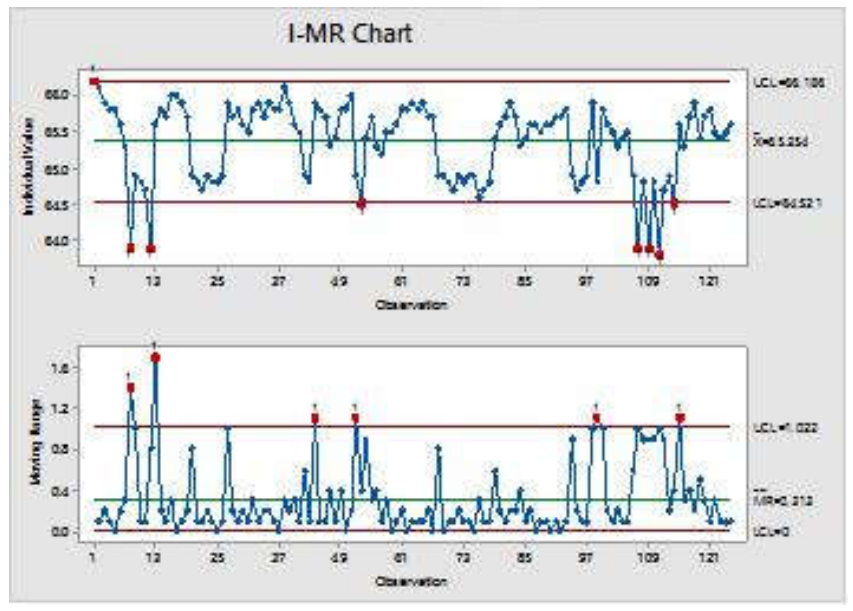

Figure 13 - Control chart of egg's weight

Control. In this step, integrated poultry industry Prima Duckindo Inc. implemented continuous improvement by Control Plan method, Risk Assessment and FMEA. The method required operational standard in the field which highly influenced process stability, therefore, a working instruction should be established. One of the causes of DOD weight which was below the standard after being processed in hatchery was the egg's weight below standard. Therefore, Control Chart for egg's weight was needed to do early control of hatching process so that high risks of non-ideal weight would not occur when DOD were delivered to the next process.

\section{CONCLUSION}

Ducks poultry business managed by Prima Duckindo Inc. with Eco-Green concept became a beneficial business and model poultry with dry house, economical, and ecofriendly. There were several superiority from the concept of poultry owned by the company, as an example, duck meat products were tastier with adequate nutrition and low cholesterol. The existence of Prima Duckindo Inc. gave positive impacts towards society economy and added the supply of meats to Indonesian citizens which still experienced deficiency of duck meats.

Prima Duckindo Inc. as a company that obey the government regulation, in establishing the poultry company, followed the regulations in the province of Banten, acquiring poultry business permit, and prioritize the preservation of the environment. Before establishing ducks poultry-company, the management team had carried out several analyses from some factors such as politics, government and laws, social and culture, demography, and natural environment. From the aspect of business, the analyses such as technology and competitive strength had been done.

By those analyses that had been done, in developing the poultry, a reliable operational management was required. Operational framework of Prima Duckindo in pre-operational stage was the result of QSPM analysis as operational objectives of the company. In the beginning of the planning activities, the company implemented project management system with its Gantt Chart. Prima Duckindo was categorized as integrated poultry company, from its breeding, hatch, growing, processing until became carcass. To achieve those objectives, therefore, operational strategies mapping was carried out comprehensively with continuous 
improvement (kaizen) since nowadays, being good was not enough, so that the company had to be the market leader which was preceded by being cost leader.

Minimizing operational cost was focused on the food cost by utilizing Azolla Microphylla and implementing eco-green system to produce good quality products and maintain the environment. To increase the production which was in line with marketing demands, partnership system was implemented as many as possible according to the capacity of DOD output from hatchery division. Determining the location for the poultry site was by using Location Factor rafting (LFR) so that the result would be objective. Based on that analysis, the location was decided in the regency of Tangerang, Kampung Blok Kelapa RT 01/01 Serdang Wetan, Sub-district of Legok.

In order to fully understand the process of ducks poultry, SIPOC analysis would assist investors and stakeholders to determine particular limitation so that structured acts which were essential for the poultry management could be formed. Production process stream planning implemented by Prima Duckindo Inc. included: DOD-PS, food, vaccine, vitamin, breeding, hatch, growing, processing, carcass, and customer.

Strategies implemented for operational activities so that the supply of raw materials did not in deficiency or surplus and to ensure the efficiency in expenses, Prima Duckindo Inc. utilized supply management system by EOQ and ROP concept. To achieve the objectives or goals as the set target, each of the stage in the process implemented systems with PFMEA, Control Plan (QCPC), Control Chart/SPC, and Risk Assessment methods.

\section{SUGGESTIONS}

Business Plan Project established by Prima Duckindo Inc. could be utilized as a model for another poultry business or ducks poultry which still utilized traditional concept. For the management in developing the company, ducks poultry-company needed innovation to develop more effective and efficient technology to produce better quality of poultry products.

Business Plan Project by Prima Duckindo Inc. could be utilized as reference for postgraduate students as materials for final projects of business. For the government, the business plan could be developed as a business which increase the prosperity of the society. The business could be a reference for the citizens or enterprise owners who intended to establish duck poultry-company.

\section{REFERENCES}

1. Budiraharjo, K. (2009). Analisis Profitabilitas Pengembangan Usaha Ternak Itik di Kecamatan Pagerbarang Kabupaten Tegal. MEDIAGRO, 5(2).

2. Chen, J. C., Li, Y., \& Shady, B. D. (2010). From value stream mapping toward a lean/sigma continuous improvement process: an industrial case study. International Journal of Production Research, 48(4), 1069-1086.

3. David, M. E., David, F. R., \& David, F. R. (2009). The Quantitative Strategic Planning Matrix (QSPM) applied to a retail computer store. The Coastal Business Journal, 8(1), 42-52.

4. De Mast, J., \& Lokkerbol, J. (2012). An analysis of the Six Sigma DMAIC method from the perspective of problem solving. International Journal of Production Economics, 139(2), 604-614.

5. George, M. L., \& George, M. (2003). Lean six sigma for service(p. 273). New York, NY: McGraw-Hill.

6. Kane, V. E. (1986). Process capability indices. Journal of quality technology, 18(1), 4152.

7. Ketaren, P. P. (2007). Peran itik sebagai penghasil telur dan daging nasional. Wartazoa, 17(3), 117-127.

8. Kompiang, I. P. (2009). Pemanfaatan mikroorganisme sebagai probiotik untuk meningkatkan produksi ternak unggas di Indonesia. Pengembangan Inovasi Pertanian, 2(3), 177-191. 
9. Lucas, J. M. (2002). The essential six sigma. Quality Progress, 35(1), 27.

10. Martin, K., \& Osterling, M. (2014). Value stream mapping. Estados Unidos de América: Shingo Institute.

11. Parkash, S., \& Kaushik, V. K. (2011). Supplier Performance Monitoring and Improvement (SPMI) Through Sipoc Analysis And PDCA Model to the ISO 9001 Qms In Sports Goods Manufacturing Industry. LogForum, 7(4).

12. Ravichandran, J. (2007). Cost-based process weights for DPMO and the overall performance of an organization. The TQM Magazine, 19(5), 442-453.

13. Sim-Tang, S. Y. (2006). U.S. Patent No. 7,096,392. Washington, DC: U.S. Patent and Trademark Office.

14. Snee, R. D. (2010). Lean Six Sigma-getting better all the time. International Journal of Lean Six Sigma, 1(1), 9-29.

15. Stevenson, W. J., \& Hojati, M. (2007). Operations management(Vol. 8). Boston: McGrawHill/Irwin.

16. Sukminiarti, N., Kususiyah, K., \& Desia, K. (2007). Populasi dan manajemen pemeliharaan Itik Talang Benih di Kelurahan Talang Benih Kecamatan Curup Kabupaten Rejang Lebong (Doctoral dissertation, Fakultas Pertanian UNIB).

17. Tague, N. R. (2005). The quality toolbox (Vol. 600). Milwaukee: ASQ Quality Press. 